Renata Michalak

https://doi.org/10.26881/pwe.2020.51.08

ORCID: 0000-0002-6578-3822

Uniwersytet im. A. Mickiewicza w Poznaniu

renmi@amu.edu.pl

\title{
Konstruktywistyczna perspektywa wczesnej edukacji przyrodniczej
}

\section{Summary \\ Constructivist perspective of early science education}

This article reflects on how to use children's natural curiosity in early science education and make learning a meaningful, joyful and useful experience for them. Therefore, an attempt was made to show the essence of the constructivist model of teaching natural science to the youngest students by referring to the strategy of teaching through inquiry and outdoor education.

Keywords: early natural education, constructivism, research processes, outdoor education, scientific inquiry

Słowa kluczowe: wczesna edukacja przyrodnicza, konstruktywizm, procesy badawcze, edukacja outdoorowa, dociekania naukowe

\section{Wprowadzenie}

Wczesna edukacja przyrodnicza rozwinęła się jako odrębna dziedzina dociekań empirycznych na przestrzeni ostatnich czterech dekad. Z dociekań tych wynika, że dzieci są niestrudzonymi badaczami - nieustannie zastanawiają się, pytają, eksplorują i rozmyślają o otaczającym ich świecie przyrodniczym oraz tworzą na jego temat własne wyobrażenia, które nieustannie rekonstruują. Wykorzystują do tego różnorodne i dostępne dla nich zasoby informacji, w tym zwłaszcza potoczne doświadczenia wyniesione z codziennych działań i przeżyć. Posługują się artefaktami, takimi jak rysunki, w celu lepszego zrozumienia fenomenów przyrodniczych, a także by wyrazić własne ich postrzeganie i rozumienie. Ponadto często dekonstruują i rekonstruują osobiste znaczenia i reprezentacje (Ravanis 2017).

Skuteczne wprowadzanie dzieci w świat przyrody opiera się na wykorzystywaniu ich naturalnej ciekawości i zachęca je do konstruowania informacji w sposób, który jest dla nich znaczący. Skupia się na doświadczeniach, które dzieci wykonują same, a nie na sposobach ich transmitowania. Kompetentny nauczyciel wczesnego nauczania przyrody najmłodszych uczniów motywuje i stymuluje ich do dywagowania, zastanawiania się, przypuszczania, zadawania pytań i badania możliwych odpowiedzi oraz konstruowania własnych wniosków. 
W licznych badaniach wskazuje się, że nauczyciele nauczają przedmiotów przyrodniczych tak, jak sami byli nauczani, a więc w sposób dydaktyczny, wymagając od swoich uczniów poznawania faktów naukowych, praw, koncepcji czy teorii za pomocą tekstów z podręcznika lub przez wypełnianie gotowych i w pełni ustrukturowanych kart pracy. Sprowadzają swoją pracę do umiejętnego przekazywania tzw. wiedzy naukowej w formie gotowej do „spożycia papki”, często wzmacnianej zaplanowanym działaniem demonstrującym ,prawdę treści”. Nauczyciele wierzą, że podręcznik zawiera wszystkie potrzebne informacje. Taka strategia nauczania zniechęca dzieci do konstruowania własnego rozumienia świata i zrozumiałych jego reprezentacji (Ulerick 1989, za: Martin i in. 2005).

W artykule tym podjęto próbę ukazania istoty konstruktywistycznego modelu nauczania przyrody najmłodszych uczniów poprzez odwołanie się do strategii nauczania przez dociekanie oraz outdoor education. W przekonaniu autorki tekstu model ten może być niezwykle efektywny w rękach samoświadomych, profesjonalnych i refleksyjnych praktyków.

\section{Implikacje konstruktywizmu dla nauczania i uczenia się przyrody}

Należy zauważyć, że konstruktywizmu jest ucieleśnieniem wielu różnych ujęć, poglądów, które pokrywają się w wielu ważnych zakresach, ale także mogą się istotnie różnić (Olusegun 2015: 66). Jest to w zasadzie teoria oparta na obserwacji i badaniach naukowych dotyczących tego, jak ludzie się uczą. Zgodnie z jej założeniami ludzie budują własne rozumienie i wiedzę o świecie w wyniku jego doświadczania i refleksji nad tym doświadczeniem (Bereiter 1994).

Z konstruktywistycznego punktu widzenia uczenie się i rozwój w naukach o wczesnym dzieciństwie są konceptualizowane jako aktywność poznawcza z naciskiem na sposób, w jaki dzieci konstruują swoją wiedzę, gdy fizycznie wchodzą w interakcję ze światem naturalnym i materialnym (Piaget 1964). Idea aktywnego konstruowania wiedzy zajmuje centralne miejsce we współczesnej psychologii i epistemologii, które są zorientowane na pojęcie uczenia się. Fundamentalnym założeniem konstruktywizmu jest więc uznanie, że ludzie konstruują wiedzę i znaczenia na podstawie swoich doświadczeń.

Sedno wczesnej edukacji przyrodniczej wspartej na konstruktywizmie psychologicznym wyraża się zatem w szczególnej relacji nauczyciela i ucznia oraz roli, jaką odgrywa każde z nich w procesie kształcenia. W konstruktywistycznej perspektywie dziecko jest aktywnym, a nie pasywnym uczestnikiem procesu zdobywania wiedzy, a więc aktywnie konstruuje wiedzę we własnym umyśle. Nauczyciel zaś pełni funkcję facylitatora, stymuluje i wspiera ucznia w procesie konstruowania wiedzy i personalnego rozumienia świata, tworząc wzbogacone środowisko uczenia się i wrażliwie motywując go do podejmowania zróżnicowanych form aktywności o charakterze badawczym.

Szczególne korzyści płynące z konstruktywistycznego paradygmatu kształcenia przyrodniczego są widoczne tam, gdzie celami nauczania jest rozwój złożonych umiejętności, takich jak rozwiązywanie problemów czy krytycznego oraz twórczego myślenia (Tam 2000). W kontekście konstruktywizmu cele kształcenia przyrodniczego ogniskują się na 
samym procesie konstruowania wiedzy i są osiągane za pomocą podejmowania przez uczniów autentycznych i zróżnicowanych zadań (Bednar i in. 1992). Uczenie się nie jest bowiem prostą reakcją na bodziec, ale procesem wymagającym samoregulacji i rozwoju struktury pojęciowej w wyniku refleksji i abstrakcji (von Glasersfeld 1995).

Konstruktywistyczny pogląd na uczenie się może wskazywać na różne praktyki nauczania. Nauczyciele-konstruktywiści zwykle zachęcają uczniów do korzystania z aktywnych technik i metod poznawania, głównie o charakterze badawczym (eksperymenty, rozwiązywanie problemów w świecie rzeczywistym, eksploracje, storyline), aby mogli samodzielnie zdobywać coraz więcej informacji, a następnie zastanowić się i porozmawiać o tym, co robią i jak zmienia się ich rozumienie (Oliver 2000).

Konstruktywizm to podejście do nauczania i uczenia się oparte na założeniu, że poznanie (uczenie się) jest wynikiem „konstrukcji umysłowej”. Innymi słowy, uczniowie uczą się, dopasowując nowe informacje do tego, co już wiedzą na dany temat. Zdaniem Davida Jonassena (1994) konstruktywizm jest często błędnie interpretowany jako teoria uczenia się, która zmusza uczniów do „ponownego wynalezienia koła”. W rzeczywistości konstruktywizm wykorzystuje i wyzwala wrodzoną ciekawość ucznia światem i tym, jak wszystko działa. Uczniowie nie wymyślają na nowo koła, ale raczej próbują zrozumieć, jak się obraca i jak działa. Angażują się, wykorzystują osobistą wiedzę i doświadczenia wyniesione z realnego świata, uczą się stawiania hipotez, testują własne pomysły i ostatecznie wyciągają wnioski ze swoich ustaleń (Olusegun 2015: 66-67).

Konstruktywiści uważają, że na uczenie się wpływają kontekst, w którym zachodzi proces poznania, a także przekonania i postawy uczniów (Olusegun 2015: 66). Odpowiednie zatem środowisko uczenia się, zwłaszcza jak najbardziej naturalne, ma niebagatelne znaczenie dla jego efektywności i przebiegu.

W kontekście dotychczasowych rozważań można wskazać korzyści, jakie płyną z konstruktywistycznej perspektywy kształcenia przyrodniczego:

- dzieci więcej się uczą i czerpią przyjemność z uczenia się przyrody, gdy są w ten proces aktywnie zaangażowane;

- efektywność nauczania przyrody jest znacznie lepsza, gdy koncentruje się na myśleniu i zrozumieniu, a nie na zapamiętywaniu faktów;

- konstruktywistyczne uczenie się przyrody jest uniwersalne i aplikacyjne. W konstruktywistycznych klasach uczniowie tworzą takie zasady funkcjonowania, które mogą stosować w innych przestrzeniach uczenia się;

- konstruktywistyczny model wczesnej edukacji przyrodniczej daje uczniom poczucie odpowiedzialności za to, czego się uczą, ponieważ uczenie się bazuje na pytaniach uczniów i ich w dużym stopniu spontanicznej eksploracji. Ponadto dzieci często biorą udział w procesie oceniania. Ocena konstruktywistyczna obejmuje inicjatywy uczniów i ich osobiste wytwory, raporty z badań, modele fizyczne i przedstawienia artystyczne. Zaangażowanie kreatywnych umiejętności rozwija zdolności dzieci do wyrażania wiedzy na różne sposoby. Ponadto dzieci są także bardziej skłonne aplikować nową wiedzę do prawdziwego życia; 
- opierając działania edukacyjne na autentycznym, rzeczywistym kontekście, konstruktywizm stymuluje i angażuje dzieci w proces poznania. Uczniowie w klasach konstruktywistycznych uczą się kwestionować powszechnie akceptowane stanowiska i opinie, negocjują znaczenia. Angażując się w takie rodzaje aktywności, dzieci zdają sobie sprawę z relatywności nauki, dostrzegają bowiem, że to, co jest uważane za realną teorię, zależy od tego, co jest znane i możliwe w danym czasie i kontekście, w którym teoria ma być stosowana (Lorsbach, Tobin 1992);

- konstruktywizm promuje umiejętności społeczne i komunikacyjne, tworząc środowisko, które bazuje na współpracy, wymianie pomysłów i dzieleniu się własnym rozumieniem świata. Pożądane jest, by dzieci w kształceniu przyrodniczym nauczyły się jasno wyrażać swoje pomysły i efektywnie współpracować przy realizacji zadań. Dlatego ważne jest, by wymieniały się pomysłami i nauczyły się ,negocjować" $\mathrm{z}$ innymi i oceniać ich wkład w społecznie akceptowany sposób. To jest niezbędne do odniesienia sukcesu w prawdziwym świecie, ponieważ uczniowie zawsze będą narażeni na różnorodne doświadczenia i będą musieli współpracować i nawigować wśród pomysłów innych (Olusegun 2015: 68).

Realizacja założeń konstruktywistycznej teorii uczenia się we wczesnej edukacji przyrodniczej, która promuje sam proces uczenia się, wymaga organizacji środowiska, które bezpośrednio aktywizuje dzieci do podejmowania działalności badawczej.

Biorąc pod uwagę poglądy Petera Honebeina (Honebein 1996, za: Olusegun 2015: 68), konstruktywistyczne środowisko kształcenia przyrodniczego dzieci cechuje się tym, że:

- zapewnia doświadczenia dla procesu konstruowania wiedzy przez uczniów (uczący się określają, w jaki sposób będą się uczyć);

- zapewnia zróżnicowane doświadczenia i docenia wiele perspektyw (ocena alternatywnych rozwiązań);

- osadza uczenie się w realistycznych kontekstach (autentyczne zadania);

- motywuje uczniów do przejmowania odpowiedzialności i decyzyjności w procesie uczenia się (uczenie się skoncentrowane na uczniu);

- osadza uczenie się w doświadczeniu społecznym (współpraca);

- stymuluje do korzystania z wielu form prezentacji (wideo, tekst audio, film itp.);

- pobudza świadomość uczniów w zakresie konstruowania wiedzy (refleksja, metapoznanie).

\section{Dociekanie badawcze fundamentem konstruktywistycznego modelu edukacji przyrodniczej najmłodszych uczniów}

Zdaniem Glykerii Fragkiadaki i in. (2019) efekty badań w dziedzinie konstruktywistycznej edukacji przyrodniczej najmłodszych uczniów pokazują, że: 1) dzieci posiadają wysokie i rozbudowane zdolności poznawcze do naukowego myślenia; 2) uczenie się i rozwój dzieci są zdeterminowane przez kontekst, taki jak: swobodne korzystanie z przedmiotów 
i materiałów, interakcje społeczne czy czynniki kulturowe; 3) trwałe rezultaty wczesnej edukacji przyrodniczej zależą od ogólnych międzydyscyplinarnych celów edukacyjnych i określonych strategii nauczania, takich jak: uczenie się oparte na dociekaniu, uczenie zintegrowane i uczenie się poprzez zabawę badawczą.

Wobec tego umożliwienie dzieciom prowadzenia badań obiektów, zjawisk, procesów po to, by mogły skonstruować własne ważne konceptualizacje, i to niezależnie od ich obiektywnej poprawności naukowej, staje się kluczowym celem wczesnej edukacji przyrodniczej. W realizacji tego celu szczególnie użyteczna może się okazać metoda dociekań zorientowana na proces uczenia się. Metoda ta zachęca i wspiera konstrukcję pojęć przez dziecko w sposób, który ma dla niego sens, co ma szczególne znaczenie w odniesieniu do zjawisk przyrodniczych, które nie są jednoznaczne (np. w przypadku pytań: czy białe proszki kuchenne wrzucone do wody rozpuszczą się lub czy ptaki odlatują na zimę, każda odpowiedź jest dobra). Wynika z tego, że dzieci należy zachęcać do poszukiwania odpowiedzi dla nich ważnych, istotnych, a nie poprawnych. To sprawia, że uczenie się staje się dla nich znaczącym doświadczeniem i ma prawdziwy sens.

O istotności wniosków decydują trzy zasadnicze cechy. Po pierwsze wniosek ma moc wyjaśniającą, co oznacza, że na dany moment stanowi zadowalające wyjaśnienie sytuacji. Po drugie wniosek daje podstawy do przewidywania. Po trzecie wniosek jest efektem pracy wielu osób. Uczeń, zanim sformułuje wniosek, bierze pod uwagę dane wyjściowe pochodzące: z jego doświadczeń, od nauczyciela, od innych uczniów, ze studiowania książek, mediów czy Internetu (Martin i in. 2005).

Wniosek jest ważny dla ucznia, gdy te trzy kryteria są spełnione i do momentu, aż zetknie się z nowym doświadczeniem, które nie pasuje do posiadanej przez niego konceptualizacji. $Z$ punktu widzenia konstruowania wiedzy przez ucznia jest to doniosły moment, krytyczny w procesie konstruowania znaczeń, ponieważ ponownie tworzy on nową konceptualizację, która jest ważna, ma moc wyjaśniającą, ma predykcję i wykorzystuje wkład innych ludzi. Konceptualizacja zostaje zrekonstruowana i pozostaje w takiej formie, dopóki uczeń ponownie nie doświadczy czegoś nowego, co zakwestionuje jego dotychczasowe myślenie czy przypuszczenia. Dociekanie jest zatem z jednej strony źródłem konfliktów poznawczych, a z drugiej - narzędziem osiągania równowagi poznawczej.

Rozbieżne wydarzenia wymagają odpowiedzi i zazwyczaj naturalnie popychają ucznia do pogodzenia tego, co się stało, z tym, o czym myślał, że się wydarzy, aby zmienić tę nierównowagę poznawczą w poznawczą równowagę lub samoregulację (Piaget 1964). Może to zrobić tylko w jeden sposób - włączając nowe doświadczenia do doświadczeń, które już wcześniej posiadał. Sposób, w jaki najefektywniej dziecko osiąga tę pożądaną równowagę poznawczą, polega na odwracaniu sytuacji, wypróbowaniu różnych pomysłów i sprawdzaniu przypuszczeń lub wyników, które wydają się obiecujące. Nauczyciel konstruktywista $\mathrm{w}$ dowolny sposób niejako naraża uczniów na nowe doświadczenia, aby zmusić ich do myślenia i zachęcić do testowania swoich pomysłów, by cały tok myślenia doprowadzić do naturalnego końca. Stawianie pytań przez nauczyciela i dzieci, dywagowanie jest swoistym motorem aktywności poznawczej. 
Metoda dociekań naukowych w ramach edukacji przyrodniczej dzieci pozwala im na konstruowanie osobistej wiedzy poprzez efektywne wykorzystywanie procesów poznawczych. Jak zauważają David Martin i in. (2005), procesy poznawcze to działania, które każdy uczący się stosuje w procesie uczenia się. Autorzy twierdzą, że naukowe przedsięwzięcie badawcze (dociekanie) może angażować aż dwanaście procesów poznawczych. Wyróżnili wśród nich procesy podstawowe i procesy zintegrowane. Do pierwszej grupy zaliczyli: 1) obserwowanie; 2) klasyfikowanie; 3) komunikowanie; 4) mierzenie; 5) przewidywanie; 6) wnioskowanie. Do drugiej: 7) identyfikowanie i kontrolowanie zmiennych; 8) formułowanie i weryfikowanie hipotez; 9) interpretowanie danych; 10) definiowanie operacyjne; 11) eksperymentowanie; 12) konstruowanie modeli/reprezentacji.

Nauczanie przyrody przez dociekanie naukowe jest niezwykle atrakcyjnym sposobem pracy z najmłodszymi uczniami. Głównie dlatego, że opiera się na wielostronnym ich zaangażowaniu $\mathrm{w}$ proces konstruowania osobistego rozumienia świata $\mathrm{i} \mathrm{w}$ ten sposób zaspokaja ich naturalną ciekawość. Uczenie się przez dociekanie bazuje na aktywacji wszystkich wymienionych procesów poznawczych, co znacznie zwiększa jego efektywność. Procesy te są zapewne powszechnie znane, ich przywołanie jednak w kontekście kształcenia przyrodniczego najmłodszych wydaje się zasadne i mam nadzieję - interesujące. Podstawowe procesy poznawcze stanowią fundament badań naukowych i ucieleśniają podstawowe umiejętności, które leżą u ich podstaw. W związku z tym ich rozwijanie należy do zasadniczych celów programu wczesnej edukacji przyrodniczej.

Obserwowanie jest w zasadzie najważniejszym procesem poznawczym. Badania zawsze opierają się na obserwowaniu, które nie tylko obejmuje widzenie, ale także słuchanie, wąchanie, smakowanie i czucie. Jednocześnie jest procesem rozumowym, który wykorzystuje wszystkie dane zmysłowe. Ważne jest zatem, aby dzieci podczas zajęć mogły angażować wszystkie zmysły w proces poznawania świata przyrodniczego i tym samym tworzyły jego bogate i zróżnicowane reprezentacje. Obserwowanie jest procesem powszechnym i niezwykle nośnym, trudno wyobrazić sobie nauczanie przyrody dzieci bez angażowania ich w ten rodzaj działalności badawczej. Jednocześnie pełni wiele znaczących funkcji dla procesu konstruowania znaczeń. Może rozbudzać ciekawość poznawczą dzieci, dawać wgląd w ich dotychczasowe rozumienie, stanowić narzędzie rekonstruowania znaczeń czy aplikowania nowych pojęć.

Kolejnym ważnym procesem aktywowanym w wyniku dociekań poznawczych dzieci jest klasyfikowanie. Umiejętność ta polega na grupowaniu przedmiotów i zjawisk według określonego kryterium. Czynności, takie jak klasyfikowanie, grupowanie, porządkowanie danych, pozwalają uczniom na ujawnianie własnych pomysłów oraz śledzenie i monitorowanie własnego procesu rozumowania. Jednocześnie prowadzą w bezpośredni sposób do wytworzenia wewnętrznych reprezentacji świata zewnętrznego, czyli jego poznawania. Klasyfikowanie to umiejętność, która przenika wiele przedsięwzięć naukowych i pozwala dzieciom zrozumieć uporządkowanie i relacje przestrzenne. Jest umiejętnością, której dzieci potrzebują, by móc dostrzegać fakty, szczegóły, własności i tworzyć z nich zbiory, uogólnienia i koncepcje. Jednocześnie służy ona identyfikacji zmiennych w trakcie for- 
mułowania hipotez podczas projektowania eksperymentów. Dzieci powinny mieć zatem możliwość klasyfikowania na wiele różnych sposobów. Ważne jest to, aby nauczyciele stwarzali im możliwość wymyślania własnych systemów klasyfikacji, tworzenia różnych kryteriów i motywowali do podejmowania ciągłych prób.

Komunikowanie jest procesem poznawczym - u jego podstaw leży wiele umiejętności, które przesycają i warunkują wszelką działalność edukacyjną ucznia. Ich nabywanie i doskonalenie następuje w różnych sytuacjach edukacyjnych i pozaedukacyjnych. W kontekście prowadzenia dociekań badawczych w ramach edukacji przyrodniczej najmłodszych chodzi o to, by dzieci miały wiele możliwości komunikowania się nie tylko podczas odpowiadania na pytania nauczyciela, ale poprzez dzielenie się swoimi spostrzeżeniami, przeżyciami, efektami pracy czy komentarzami do poszczególnych etapów dociekań. W trakcie komunikowania się ważne jest, by nauczyciele prosili uczniów o jasne opisywanie tego, co zobaczyli, zrobili, zaobserwowali, przewidzieli i pomyśleli. Jest to szczególnie istotne, gdyż dzieci najpierw uczą się rozpoznawać przedmioty i zdarzenia, opatrując je desygnatami w postaci słów, pojęć, a następnie uczą się je opisywać, by wreszcie wyrażać swoje myśli w sposób, w jaki potrafią to inni ludzie (Martin i in. 2005).

Proces pomiaru w odniesieniu do edukacji przyrodniczej najmłodszych uczniów obejmuje pięć aspektów: 1) długość; 2) objętość; 3) ciężar; 4) temperaturę i 5) czas (Martin $\mathrm{i}$ in. 2005). U jego podstaw leżą czynności, które nie tylko testują poziom sprawności matematycznych dzieci, ale uczą je myślenia i logicznego rozumowania. Pomiar jest działalnością naukową, która zwykle odbywa się podczas prowadzenia eksperymentu. W jego wyniku uzyskuje się tzw. twarde dane, które determinują przebieg, cechy lub zależności badanych zjawisk. W procesie kształtowania umiejętności dokonywania pomiarów ważne jest to, by uczniowie nie tylko poznawali narzędzia pomiaru, ale wymyślali i korzystali z niekonwencjonalnych narzędzi i sposobów mierzenia.

Przewidywanie to kolejny podstawowy proces poznawczy, który zachodzi, gdy dzieci próbują udzielić odpowiedzi na pytanie: co by się stało, gdyby... lub co się stanie, gdy... Aktywuje się szczególnie wtedy, gdy dzieci zmagają się ze zróżnicowanymi zadaniami typu otwartego i półotwartego. Proces ten wymaga samodzielności myślenia, zaufania do swoich kompetencji i skłonności do poszukiwania własnych rozwiązań. Te cechy myślenia kształtują się w warunkach, w których uczeń podejmuje wysiłek samodzielnego i kooperatywnego rozwiązywania zadań trudnych, złożonych, z reguły zakończonych sukcesem. W przeciwnym razie uczeń będzie zawsze liczył na pomoc innych osób i poszukiwał gotowych rozwiązań. Dobrze rozwinięta umiejętność prognozowania pozwala uczniom planować różne alternatywne strategie rozwiązywania zadań na podstawie analizy ich celu i danych początkowych, ale jednocześnie wymaga twórczego, logicznego i krytycznego myślenia. Dziecko nabywa i rozwija tę umiejętność, podobnie jak pozostałe umiejętności poznawcze, tylko w wyniku podejmowania całego zespołu zróżnicowanych i zorganizowanych czynności poznawczych lub poznawczo-motorycznych mających na celu zrealizowanie zwykle złożonego zadania o charakterze badawczym. Przewidywanie to sposób, w jaki dziecko opisuje na podstawie obserwacji, 
doświadczenia lub uzasadnienia naukowego, co wydarzy się w danej sytuacji lub co może się stać, gdy podejmie określone działanie.

Kolejny proces poznawczy aktywowany w procedurze dociekań naukowych to wnioskowanie. Polega on na uogólnianiu wyników uzyskanych podczas testowania zmiennych i stanowi potwierdzenie bądź odrzucenie hipotezy. Wnioskowanie to proces rozumowy, który wymaga myślenia przyczynowo-skutkowego oraz dobrych umiejętności analitycznych i syntezy. W edukacji przyrodniczej należy zachęcać dzieci do wyciągania wniosków na podstawie danych czy wyników podejmowanych działań wtedy, gdy jest to tylko możliwe. W procesie wnioskowania ważne jest, by uczniowie nie tylko komunikowali swoje wnioski, ale także je uzasadniali. Wnioskowanie bez powodu staje się bezużyteczne i mało atrakcyjne dla dzieci.

W nauczaniu przedmiotów ścisłych i przyrodniczych dzieci powinny się koncentrować na podstawowych procesach, choć już wiele dzieci przedszkolnych jest gotowych wyjść poza te podstawowe procesy, co widać w jakości zadawanych przez nie pytań. Kathleen Metz (1995) oraz Russell Tytler i Suzanne Peterson (2004) twierdzą, że już dzieci przedszkolne są rzeczywiście zdolne do manipulowania zmiennymi, podejmowania aktywności badawczej i wykonywania eksperymentów, a także przytaczania dowodów na poparcie swoich wniosków.

Eksperymentowanie jest najtrudniejszym rodzajem działalności badawczej, ponieważ wymaga ściśle określonej procedury. Polega na celowym wywołaniu określonego zjawiska w sztucznie stworzonych warunkach i badaniu jego przebiegu, cech lub zależności. Celem eksperymentu jest najczęściej weryfikacja hipotezy. Inaczej mówiąc, eksperymentowanie jest ustaleniem wpływu oddziaływania jednej zmiennej na drugą. Eksperymenty odpowiednie dla dzieci mogą dotyczyć zbadania, jaka tkanina będzie najlepsza na uszycie kombinezonu dla strażaka, jak najszybciej wysuszyć pranie czy jak skrócić długość hamowania pojazdu itp.

Ostatni z wyróżnionych tu procesów zintegrowanych - konstruowanie modeli - polega na budowaniu lub rysowaniu reprezentacji obiektów, zjawisk lub pojęć, których nie można zobaczyć ani bezpośrednio zmierzyć. Powszechnie używane modele to zwykle reprezentacje układu słonecznego, faz księżyca, dinozaurów, egzotycznych kwiatów lub zwierząt itp. Modele możliwe do tworzenia przez najmłodszych uczniów to np.: powstawanie tęczy przy użyciu pryzmatu lub węża z wodą w słoneczny dzień, erupcja wulkanu z zastosowaniem sody i octu, konstruowanie cząsteczki wody, układu słonecznego, rozchodzenia się dźwięku i wiele innych.

Metoda dociekań zorientowana na proces stanowi egzemplifikację konstruktywistycznego sposobu nauczania przedmiotów przyrodniczych najmłodszych uczniów. Proces dociekań badawczych oparty na poszukiwaniu i odkrywaniu nowych informacji, doświadczeń, wiedzy stopniowo i w naturalny sposób przeprowadza ucznia od koncepcji potocznych do koncepcji naukowych, od osobistego do społecznego rozumienia świata, od subiektywizmu do obiektywizmu naukowego. Jest to droga zgodna z naturalnym rytmem rozwoju dziecka, które rodzi się z instynktem odkrywcy i badacza. Należy zatem uczynić 
wszystko, by nie zaprzepaścić tej naturalnej właściwości dziecięcego umysłu - warto ją aktywować i stymulować w procesie kształcenia przyrodniczego.

\section{Outdoor education egzemplifikacją konstruktywistycznego modelu wczesnej edukacji przyrodniczej}

Outdoor education rozumiana jest tak, jak to czyni m.in. Peter Mitchell (2018: 19) - jako planowane, intencjonalne tworzenie warunków do uczenia się uczniów na świeżym powietrzu, które sprzyja odkrywaniu i eksperymentowaniu, dokonuje się w bezpośrednim kontakcie ze światem przyrody. To właśnie przyroda tworzy bogaty kontekst sprzyjający angażowaniu się uczniów w złożone interakcje społeczne, ich integracji, dobremu samopoczuciu i rozwojowi, a także uruchamianiu indywidualnych oraz grupowych procesów uczenia się (Michalak, Parczewska 2019).

Edukacja w bezpośrednim kontakcie z naturą, mimo że ciągle niedoceniana, została wprowadzona do szkół wraz z realizacją koncepcji nauczania poglądowego, stworzonej w XVII w. przez Jana Amosa Komeńskiego. Obecnie najczęściej przyjmuje formy: zajęć, ćwiczeń i gier terenowych, ścieżek dydaktycznych czy wycieczek. Bezpośredni kontakt z przyrodą podczas tego typu zajęć pozwala uczniom obserwować i odkrywać zjawiska, prawa, zależności, procesy, które są wpisane w program nauczania na dany etap kształcenia. Uczniowie mają wiele okazji do samodzielnej i spontanicznej aktywności, kierowanej osobistymi zainteresowaniami i dociekliwością poznawczą. Z punktu widzenia wszystkich podstawowych i złożonych procesów poznawczych istotnych w procesie nabywania wiedzy, a także jej utrwalania i aplikowania edukacja na świeżym powietrzu stwarza optymalne warunki do ich zaistnienia.

Edukacja w środowisku przyrodniczym jest konieczną alternatywą dla tradycyjnej edukacji, przede wszystkim z powodu jej atrakcyjności dla ucznia i jej wysokiej efektywności. Odpowiednio zorganizowana edukacja outdoorowa może gwarantować nie tylko nabywanie i wzbogacanie kompetencji w obszarze przyrodniczym poprzez bezpośrednie obcowanie z ekosystemami, ale także może być niezwykle użyteczna w nabywaniu kompetencji specyficznych dla każdego obszaru kształcenia i holistycznie rozumianego rozwoju ucznia. Wyniki badań prowadzonych na przestrzeni ostatnich kilkunastu lat świadczą o tym, że edukacja outdoorowa tworzy niezwykle urozmaiconą przestrzeń stymulującą uczniów do angażowania się w proces indywidualnego oraz grupowego uczenia się, podejmowania złożonych interakcji społecznych, sprzyja też dobremu samopoczuciu i rozwojowi fizycznemu oraz poznawczo-emocjonalnemu (Maynard, Waters 2007; Waite 2011; Brown 2008; Louv 2010; Smith 2010; Wattchow, Brown 2011). Naukowcy z wielu części świata, np.: ze Szwecji (Dahlberg i in. 2007; Niklasson, Sandberg 2010), Norwegii (Melhuus 2012), Stanów Zjednoczonych (Louv 2010), Anglii (Prince 2018) czy Estonii (Tuuling i in. 2018), powołując się na własne badania, potwierdzają znaczenie edukacji na świeżym powietrzu dla wspierania i poprawy funkcjonowania i rozwoju uczniów. 
Outdoor education stwarza dzieciom możliwość aktywnego kształtowania siebie oraz środowiska uczenia się, co pomaga im w nabywaniu kompetencji poznawczych i metakognitywnych (Wells 2000) oraz wspiera funkcjonowanie tych, które z jakichś powodów nie odnoszą sukcesów w tradycyjnie rozumianym procesie kształcenia (Taylor $\mathrm{i}$ in. 2002; Wells, Evans 2003; Kuo, Taylor 2004). Działania w naturalnym środowisku służą nabywaniu i wzbogacaniu wielu kompetencji pomijanych w formalnych programach nauczania, zwanych „kompetencjami miękkimi”, wśród których warto wskazać na: poczucie autonomii, odpowiedzialności, sprawstwa, współpracy, radzenia sobie z porażką oraz empatię i umiejętności przywódcze (Blair 2009).

Przestrzeń obejmująca cały budynek, teren przyległy do niego, jak również miejsca mniej lub bardziej oddalone, takie jak: park, ogród, staw, rzeka, pole uprawne czy las, może stanowić naturalny kontekst wszechstronnej edukacji ucznia. Odpowiednio zorganizowana i zaaranżowana będzie dla niego źródłem nie tylko spontanicznych, przypadkowych, żywiołowych doświadczeń, ale przede wszystkim doświadczeń zamierzonych, planowanych i systematycznych, wyznaczonych założeniami procesu kształcenia. Bogactwo owej przestrzeni, a przede wszystkim umiejętność jego wykorzystania będzie determinowała bogactwo doświadczeń uczących się. Należy mocno podkreślić, że nie chodzi tu o liczbę elementów oraz ich różnorodność, choć zapewne jest to ważne, ale o różnorodność szans doświadczania nowych przeżyć poznawczych i emocjonalnych, które pozwalają uczniom przekraczać aktualne możliwości. Przestrzeń ta będzie tym cenniejsza edukacyjnie, im w większym stopniu będzie stwarzać warunki do samodzielnego, twórczego i kooperatywnego działania uczniów. Co więcej, silniej będzie ich stymulować do podejmowania różnorodnych form aktywności wymagających wysiłku intelektualnego, niestandardowych sposobów funkcjonowania, namysłu oraz refleksji, hipotetycznego myślenia, a także sprawdzania wielu alternatywnych idei oraz pomysłów rozwiązania trudnych, ale ważkich i użytecznych zadań (Michalak, Parczewska 2019).

Strategia edukacji outdoorowej ze względu na jej niezaprzeczalne walory jest fundamentalna w nauczaniu przyrody, a odpowiednio wykorzystana może stanowić ucieleśnienie konstruktywistycznego modelu wprowadzania dzieci w świat przyrody. Biorąc pod uwagę etapy konstruowania wiedzy w całym procesie kształcenia, można wyróżnić trzy zasadnicze jego etapy: wstępny, zasadniczy i końcowy. Bezpośrednie obcowanie dzieci $\mathrm{z}$ naturą $\mathrm{i} \mathrm{w}$ naturze przyczynia się do maksymalizowania szans powodzenia każdego z nich.

Etap wstępny obejmuje dwa główne działania nauczyciela: 1) przygotowanie uczniów na nowe doświadczenia i 2) organizację przestrzeni edukacyjnej. Jego istota zawiera się w zorientowaniu uczniów na przedmiot poznania i oszacowaniu ich przedwiedzy w tym zakresie. Podczas tego etapu nauczyciel dąży do zachwiania równowagi poznawczej ucznia przez dostarczanie mu nowych i atrakcyjnych bodźców skupiających jego uwagę na treściach, które mają się stać przedmiotem poznania. Chodzi zatem o wzbudzenie ogólnej aktywności ośrodkowego układu nerwowego (OUN), która odpowiada za gotowość uczącego się do przetwarzania informacji sensorycznych. Ważne jest przy tym zadbanie 
o atmosferę bezpieczeństwa psychicznego uczniów, a więc dobrego ich samopoczucia ograniczającego nadmierny stres przed nowym i nieznanym (Petlak, Zajacová 2010: 55).

Etap wstępny polega w zasadzie na zainteresowaniu dziecka przedmiotem poznania. W klasie nauczyciel musi włożyć wiele wysiłku w to, by rozbudzić ciekawość poznawczą dzieci, ich zainteresowanie oraz motywację wewnętrzną do podjęcia wysiłku mentalnego. Nierzadko ucieka się do różnych pracochłonnych sposobów, które i tak mogą być dla dziecka obce i niecelne. Natura zaś jest źródłem niezwykle zróżnicowanych i atrakcyjnych dla dziecka bodźców i nawet przy niewielkim wkładzie nauczyciela wywołuje dziecięce zainteresowanie, emocjonalne zaangażowanie, tak bardzo istotne w całym procesie uczenia się i to nie tylko przyrody. Często właśnie to spontaniczne zainteresowanie staje się motorem procesu poznania, zarówno co do treści, jak i formy. Powalony na drodze konar po burzy, leżący na plecach żuk, który bezowocnie próbuje się odwrócić, rozbite szkło, które w słoneczny dzień mieni się kolorami tęczy, czy misternie utkana pajęczyna, w której szamocze się mucha, wywołują naturalne zaciekawienie dziecka, które może być wykorzystane przez nauczyciela jako początek procesu poznania zjawisk, obiektów i procesów przyrodniczych. Przebywanie w środowisku pozwala nauczycielowi łatwiej zachęcić uczniów do uczenia się i naturalnie wniknąć w ich osobistą wiedzę, ocenić ich dotychczasowe rozumienie, a więc wyczuć moment startowy procesu konstruowania wiedzy. Powodzenie etapu wstępnego zależy także od atmosfery, jaka towarzyszy funkcjonowaniu uczniów i nauczycieli w procesie kształcenia. Natura tworzy aurę spokoju i odprężenia, jest źródłem ukojenia i doznań, które pozwalają na szybki powrót do równowagi psychicznej. Poza tym zazwyczaj pozbawiona jest negatywnych emocji o dużej sile, które blokują procesy pamięci.

Etap zasadniczy procesu kształcenia, opisany językiem czołowych twórców konstruktywizmu, polega na otwieraniu strefy najbliższego rozwoju dziecka i asymilacji nowych doświadczeń, a więc restrukturyzacji wiedzy. Jest to etap poszukiwania, odkrywania i zderzania się ucznia z nowym doświadczeniem, które stara się on włączyć do posiadanych już struktur psychicznych. Mówiąc prościej - jest to faza konstruowania nowych znaczeń. Proces ten nie jest jednak łatwy i natychmiastowy. Dziecko stara się zrozumieć dane doświadczenie, nadać mu znaczenie i tak przetworzyć, by właściwie bezkolizyjnie je zasymilować. Etap ten nie jest zatem pozbawiony błędów. Ważne jest, by nauczyciel wrażliwie towarzyszył dziecku w procesie przyswajania nowych informacji. Błędy łatwiej naprawić podczas procesu niż dopiero po jego zakończeniu, gdy połączenia synaptyczne ulegną już umocnieniu. Oczywiście nie chodzi tu o korygowanie przez przekazywanie gotowych znaczeń, ale pobudzenie dziecka do refleksji i ukierunkowanej aktywności przez stawianie odpowiednich pytań. Edukacja poza budynkiem stwarza bardzo korzystne warunki do restrukturyzacji wiedzy przyrodniczej dzieci poprzez bezpośrednie zdobywanie i odkrywanie informacji o świecie przyrodniczym. Aktywna interakcja z obiektami, bezpośrednia możliwość obserwowania zjawisk i zdarzeń, testowanie swojej dotychczasowej wiedzy w kontakcie z rzeczywistością, wielozmysłowe zaangażowanie oraz przeżywanie sprzyjają konstruowaniu osobistej wiedzy poprzez asymilację nowych dla ucznia doświadczeń 
i akomodację do nich tych dotychczas posiadanych (Michalak, Parczewska 2019). Na tym etapie ważne jest to, by nauczyciel zadbał o różnorodność i atrakcyjność metod organizacji nowych doświadczeń. W naturze dzieci mogą podejmować zróżnicowane formy aktywności badawczej, takie jak: eksploracja, obserwacja, klasyfikowanie, eksperymentowanie, hipotetyzowanie, mierzenie, wnioskowanie, dyskutowanie itp. Edukacja outdoorowa sprzyja prowadzeniu wywiadów, storyline, wykorzystywaniu technik dramowych i metody projektu, mapowaniu terenu, a także bieganiu przełajowemu i na azymut. Poza tym stwarza szczególnie dogodne warunki do rejestracji doświadczeń za pomocą narzędzi optycznych, cyfrowych czy technik plastycznych i muzycznych. Ważne, by panowały w niej różnorodność i kolektywne formy pracy. W kontekście procesu kształcenia można powiedzieć, że wszystkie te sposoby przyczyniają się do uzyskiwania wielomodalnego materiału nauczania, zróżnicowanego co do treści i formy, sprzyjają także testowaniu dotychczasowej wiedzy i opanowanych technik adaptacyjnych, co przyczynia się do konstruowania wiedzy nie tyle deklaratywnej, ile proceduralnej i kontekstowej.

Etap końcowy konstruktywistycznego procesu kształcenia przyrodniczego dzieci to czas utrwalania nowej wiedzy przez jej aplikację w różnorodnym kontekście - bliskim i jak najbardziej realnym. Na tym etapie połączenia synaptyczne zostały już wytworzone, choć ciągle podlegają zmianom i modyfikacjom. Nie mają jeszcze charakteru na tyle trwałego, by stwierdzić, że już pierwsze zetknięcie ucznia z nowym materiałem pozwoli mu go dokładnie zapamiętać, zrozumieć i zastosować. To wymaga czasu i wyćwiczenia oraz utrwalenia skonstruowanych przez różne obszary mózgu dróg neuronalnych. Utrwalaniu sprzyja wielokrotne powracanie do danych treści i ich aplikowanie do rozwiązywania różnych zadań i sytuacji problemowych (Michalak 2013). Bardzo ważne jest, by dzieci próbowały rozwiązywać te problemy, których naturalnie doświadczają, podejmując działania w środowisku. Zdobyte doświadczenia z poprzednich faz nauczania pozwalają im z zupełnie innej perspektywy znaczeniowej projektować strategie rozwiązywania problemów, które jeszcze nie tak dawno leżały poza ich możliwościami poznawczymi. To daje dzieciom poczucie sprawstwa i zadowolenia z wysiłku, jaki towarzyszył im podczas uprzednich konfrontacji. Sprzyjają temu metody pracy stymulujące uczniów do tworzenia planów, projektów, raportów, formułowania nowych twierdzeń, założeń i hipotez oraz wyciągania wniosków i wizualizacji osobistych doświadczeń. Ponadto warto na tym etapie sięgać po różnego typu gry i konkursy, quizy i kalambury, które uczniowie uwielbiają. Mogą one stanowić świetną okazję do utrwalenia nowej wiedzy, a jednocześnie dają nauczycielowi wgląd w to, czy proces uczenia się przyniósł spodziewane rezultaty. Warto zauważyć, że źródłem refleksji nad doświadczeniami uczniów wyniesionymi z zajęć outdoorowych może być także komentarz nauczyciela. Jego wiedza merytoryczna i kompetencje metodyczne sprzyjają budowaniu pomostów pomiędzy tym, co uczniowie samodzielnie odkryli, a tym, co naukowe i społecznie usankcjonowane (Michalak, Parczewska 2019).

Organizowanie zatem edukacji outdoorowej ma głęboki sens pedagogiczny, ponieważ stanowi ona niebanalny kontekst konstruowania i rekonstruowania wiedzy przyrodniczej przez każde autentycznie i wielostronnie zaangażowane dziecko. Bezpośredni kontakt 
z przyrodą i wszystkim, co się w niej znajduje i zachodzi, co trwa niezmiennie i co podlega dynamicznym przemianom, co zaskakuje, wywołuje zachwyt, radość lub obrzydzenie, co stanowi podstawę ludzkiej egzystencji oraz rozwoju i jest na wyciągnięcie ręki każdego dziecka, które wyposażone przez naturę w ciekawość może bez większego trudu poznać i zrozumieć, stanowi najbardziej naturalne środowisko nauczania. Wszystko, co dokonuje się w klasie podczas procesu kształcenia, a dotyczy przyrody, jest jedynie jego nieudolną i - jak wskazuje się w badaniach - mało efektywną repliką.

\section{Zakończenie}

Podsumowując rozważania dotyczące konstruktywistycznej perspektywy uczenia się i nauczania przyrody dzieci należy stwierdzić, że: 1) każde dziecko ma wcześniejsze doświadczenia wyniesione z aktywnej relacji ze światem przyrodniczym, które zapoczątkowują proces konceptualizacji; 2) każde dziecko ma inną aktualną wiedzę dotyczącą świata przyrodniczego; 3) każde włącza nowe informacje, doświadczenia do swojej aktualnej wiedzy i czyni to na różne sposoby; 4) każde kończy ten proces z inną, ale własną konstrukcją wiedzy; 5) dlatego każde dziecko konstruuje inne rozumienie lub konceptualizacje (Martin i in. 2005).

Konstruktywistyczny paradygmat uczenia się i nauczania dzieci wyraża się w uznaniu założenia, że dzieci konstruują własne konceptualizacje, jako priorytetowego i fundamentalnego dla wszelkiej działalności o charakterze edukacyjnym. Dlatego zaleca się, by nauczyciele zamiast postępowania dydaktycznego, opartego na instrukcji i poprawności metodycznej, tworzyli konstruktywistyczne środowisko uczenia się przyrody, które stymuluje dzieci do podejmowania zróżnicowanych form aktywności o charakterze badawczym. Umożliwienie dzieciom prowadzenia badań po to, by mogły skonstruować własne ważne konceptualizacje i to niezależnie od ich obiektywnej poprawności naukowej, staje się kluczowym celem wczesnej edukacji przyrodniczej. Starajmy się zatem czynić edukację przyrodniczą przestrzenią szczęśliwego i twórczego rozwoju dziecka przez wspólne podążanie drogą podróżnika i odkrywcy. Nie obawiajmy się luk w wiedzy, bo to właśnie brak znajomości gotowej odpowiedzi na pytanie popycha ucznia i nauczyciela do działania, dostarcza radości odkrywcy, będącą immanentną cechą dziecka, którą tak łatwo zagubić w procesie tradycyjnej, nazbyt instruktażowej edukacji.

\section{Literatura}

Bednar A.K., Cunningham D.J., Duffy T.M., Perry J.D. (1992), Theory into practice: How do we link? W: Duffy T.M., Jonassen D.H. (eds.), Constructivism and the technology of instruction. Hillsdale, NJ, Lawrence Erlbaum Associates.

Bereiter C. (1994), Constructivism, Socioculturalism, and Popper's World 3. „Educational Researcher", 23(7). 
Blair D. (2009), The child in the garden: an evaluative review of the benefits of school gardening. „Journal of Environmental Education”, 40(2).

Brown M. (2008), Comfort zone: model or metaphor? „Australian Journal of Outdoor Education”, 12(1). https://www.academia.edu/14271955/Comfort_Zone_Model_or_Metaphor, 12.06.2020.

Dahlberg G., Moss P., Pence A. (2007), Beyond quality in early childhood education and care. London, Routledge.

Fragkiadaki G., Fleer M., Ravanis K. (2019), A cultural-historical study of the development of children's scientific thinking about clouds in everyday life. „Research in Science Education”, 49(6). https://www.sciencedirect.com/science/article/pii/S221065612030132X?dgcid=author, 20.09.2020.

Jonassen D.H. (1994), Toward a Constructivist Design Model. „Educational Technology”, 34(4).

Kuo F.E., Taylor A.F. (2004), A Potential Natural Treatment for Attention Deficit/Hyperactivity Disorder: Evidence from a National Study. „American Journal of Public Health”, 94(9). https:// www.researchgate.net/publication/8379683_A_Potential_Natural_Treatment_for_Attention-DeficitHyperactivity_Disorder_Evidence_From_a_National_Study\#fullTextFileContent, 29.09.2020

Lorsbach A.W., Tobin K. (1992), Constructivism as a referent for science teaching. W: Lorenz F., Cochran K., Krajcik J., Simpson P. (eds.), Research Matters... to the Science Teacher. Manhattan, KS, National Association for Research in Science Teaching.

Louv R. (2010), Last Child in the Woods: Saving our Children from Nature-Deficit Disorder. London, Atlantic Books.

Martin D.J., Jean-Sigur R., Schmidt E. (2005), Process-Oriented Inquiry - A Constructivist Approach to Early Childhood Science Education: Teaching Teachers to Do Science. „Journal of Elementary Science Education", 17(2).

Maynard T., Waters J. (2007), Learning in the outdoor environment: A missed opportunity. Early Years. „An International Journal of Research and Development”, 27(3).

Melhuus L.C. (2012), Outdoor day-care centers - acculturalization of nature: how do children relate to nature as educational practice? „European Early Childhood Education Research Journal", 20.

Metz K. (1995), Reassessment of developmental constraints on children's science instruction. „Review of Educational Research", 65.

Michalak R. (2011), Poznawanie świata przyrody jako kontekst rozwoju kompetencji poznawczych trzecioklasistów. W: Sowińska H. (red.), Dziecko w szkolnej rzeczywistości. Założony a rzeczywisty obraz edukacji elementarnej. Poznań, Wydawnictwo Naukowe Uniwersytetu im. Adama Mickiewicza.

Michalak R. (2013), Dziecko u progu edukacji przedmiotowej. Studium teoretyczno-empiryczne. Poznań, Wydawnictwo Naukowe Uniwersytetu im. Adama Mickiewicza.

Michalak R., Parczewska T. (2019), (Nie)obecność outdoor education w kształceniu szkolnym. Lublin, Wydawnictwo Uniwersytetu Marii Curie-Skłodowskiej.

Mitchell P. (2018), What is outdoor education? W: I. Lisin, P. Kida (eds.), Outdoor education from theory to practice. Wrocław, Foundation Institute of Animation and Social Development.

Niklasson L., Sandberg A. (2010), Children and the outdoor environment. „European Early Childhood Education Research Journal", 18(4). 
Oliver K.M. (2000), Methods for developing constructivism learning on the web. „Educational Technology", 40(6). https://www.jstor.org/stable/44428633?seq=1\#metadata_info_tab_contents, 26.09.2020.

Olusegun S. (2015), Constructivism Learning Theory: A Paradigm for Teaching and Learning. „IOSR Journal of Research \& Method in Education”, 5(6). http://iosrjournals.org/iosr-jrme/papers/Vol-5\%20Issue-6/Version-1/I05616670.pdf, 29.09.2020.

Petlak E., Zajacová J. (2010), Rola mózgu w uczeniu się. Kraków, Wydawnictwo PETRUS.

Piaget J. (1964), Development and learning. „Journal of Research in Science Teaching”, 2(3). https://onlinelibrary.wiley.com/doi/epdf/10.1002/tea.3660020306, 1.10.2020.

Prince H.E. (2018), Changes in outdoor learning in primary schools in England, 1995 and 2017: lessons for good practice. „Journal of Adventure Education and Outdoor Learning”, 19.

Ravanis K. (2017), Early childhood science education: State of the art and perspectives. „Journal of Baltic Science Education", 16(3).

Smith P.K. (2010), Children and Play. Chichester, Wiley-Blackwell.

Tam M. (2000), Constructivism, Instructional Design, and Technology: Implications for Transforming Distance Learning. „Educational Technology and Society”, 3(2). https://www.researchgate.net/publication/26391080_Constructivism_Instructional_Design_and_Technology_Implications_for_Transforming_Distance_Learning, 25.09.2020.

Taylor A.F., Kuo F.E., Sullivan W.C. (2002), Views of Nature and Self-Discipline: Evidence from Inner City Children. ,Journal of Environmental Psychology”, 22(1-2). https://doi.org/10.1006/ jevp.2001.0241, 15.10.2018.

Tuuling L., Õun T., Ugaste A. (2018), Teachers'opinions on utilizing outdoor learning in the preschools of Estonia. „Journal of Adventure Education and Outdoor Learning”, 19(4). https:// www.researchgate.net/publication/329446170_Teachers\%27_opinions_on_utilizing_outdoor learning_in_the_preschools_of_Estonia, 12.03.2020.

Tytler R., Peterson S. (2004), From "Try it and see” to strategic exploration: Characterizing young children's scientific reasoning. „Journal of Research in Science Teaching”, 41(1).

von Glasersfeld E. (1995), A constructivist approach to teaching. W: L.P. Steffe, J. Gale (eds.), Constructivism in education. Hillsdale, NJ, Lawrence Erlbaum Associates.

Waite S. (2011), Teaching and learning outside the classroom: Personal values, alternative pedagogies and standards. „Education 3-13”, 39(1).

Wattchow B., Brown M. (2011), A Pedagogy of Place. Melbourne, Monash University Publishing.

Wells N.M. (2000), At Home with Nature: Effects of 'Greenness' on Children's Cognitive Functioning. „Environment and Behavior”, 32(6).

Wells N.M., Evans G.W. (2003), Nearby Nature: A Buffer of Life Stress Among Rural Children. „Environment and Behavior", 35(3). 